\title{
Cytokinins résumé: their signaling and role in programmed cell death in plants
}

\author{
A. Kunikowska $\cdot$ A. Byczkowska $\cdot$ M. Doniak $\cdot$ \\ A. Kaźmierczak
}

Received: 20 December 2012/Revised: 22 March 2013/Accepted: 25 March 2013/Published online: 12 April 2013

(C) The Author(s) 2013. This article is published with open access at Springerlink.com

\begin{abstract}
Cytokinins (CKs) are a large group of plant hormones which play a crucial role in many physiological processes in plants. One of the interesting functions of $\mathrm{CKs}$ is the control of programmed cell death (PCD). It seems that all CKs-dependent phenomena including PCD are accompanied by special multi-step phosphorelay signaling pathway. This pathway consists of three elements: histidine kinase receptors (HKs), histidine phosphotransfer proteins (HPs) and response regulators (RRs). This review shows the résumé of the latest knowledge about CKs signaling pathways in many physiological processes in plants with special attention paid to PCD process.
\end{abstract}

Keywords Cytokinin - Cytokinin signaling - Kinetin · PCD

\section{Introduction}

Programmed cell death (PCD) is a process that normally occurs during seed germination, development and senescence. This process is crucial for proper functioning of all multicellular organisms, both plants and animals (Kunikowska et al. 2012; Carimi et al. 2003; Collazo et al. 2006). The latest knowledge classifies PCD process on the

Communicated by P. Kumar.

A contribution to the Special Issue: Plant Hormone Signaling.

A. Kunikowska · A. Byczkowska · M. Doniak

A. Kaźmierczak ( $\square)$

Department of Cytophysiology, Faculty of Biology

and Environmental Protection, University of Łódź,

Pomorska 141/133, 90236 Łódź, Poland

e-mail: kazand@biol.uni.lodz.pl; kazma@interia.pl basis of changes in cell morphology (van Doorn et al. 2011). In animals, apoptosis, autophagy and necrosis are distinguished. In plants, categorization of cell death is more complicated but in 2011 van Doorn et al. proposed the application of morphological criteria to recognize plant cell death thus vacuolar, necrotic and mixed or atypical forms of cell death. Another classification system was also proposed to describe plant PCD. It includes two classes of cell death called "autolytic" and "non-autolytic" which describe processes that occur in intact plants but not in cell cultures (van Doorn 2011).

However, both in animals and plants, changes in the nucleus morphology, especially chromatin condensation and degradation, are the major common morphological features (van Doorn 2011).

Programmed cell death is defined as the genetically determined suicide of individual cells in response to pathogens, environmental stress, and during normal development (Gladish et al. 2006; Collazo et al. 2006) it may be also exogenously induced (Carimi et al. 2003, 2004; Kunikowska et al. 2012).

Up till now, it has been discovered that two natural cytokinins (CKs) - kinetin and benzylaminopurine (BAP or benzyladenine, BA) - at high concentrations are able to induce PCD in plants (Kunikowska et al. 2012; Vescovi et al. 2012; Carimi et al. 2003, 2004). Recent studies have shown that BAP is able to induce PCD in plant cultured cells (Carimi et al. 2003, 2004; Vescovi et al. 2012), whereas kinetin induces this process only in living plant tissues (Kunikowska et al. 2012).

Cytokinins are a large group of plant hormones. They appear to be synthesized in QC (a quiescence center) of roots which seems to be crucial for this synthesis. In cells, CKs are present in chloroplasts or as complexes bound with tRNA (van Staden et al. 2008). These chemical 
compounds occur endogenously at very low concentrations (pmol g ${ }^{-1} \mathrm{FW}$; Doležal et al. 2007). Cytokinins play a pivotal role at many stages of plant growth and development (Sakakibara 2006; Choi and Hwang 2007). They were discovered during the 1950s as factors essential for cell division (Barciszewski et al. 2007; Mazid et al. 2011) in the presence of auxins (Carimi et al. 2003). Since this discovery, endogenous CKs have been shown as active molecules involved in seed germination, leaf senescence, nutrient mobilization, apical dominance, formation and activity of shoot apical meristem (Mazid et al. 2011) and development of vasculature (Choi et al. 2011). They also promote seed germination, starch and chlorophyll production, bud differentiation and branching (Doležal et al. 2007). Cytokinins influence plant shape depending on environmental factors, such as light, water and nutrition (Hirose et al. 2008). There is also evidence that CKs are involved in the modulation of metabolism and morphogenesis during environmental stress (Hirose et al. 2008).

It seems that $\mathrm{CK}$ receptors are involved in many physiological processes including CK-dependent PCD. These receptors could act as a multi-step phosphorelay system which functions like histidine kinase (HK; Schaller et al. 2011).

\section{Characteristic of natural and synthetic cytokinin properties}

Cytokinins are $\mathrm{N}^{6}$-substituted adenine derivates. Isopentenyl pyrophosphate is the starting compound in $\mathrm{CK}$ synthesis pathway (Sakakibara 2006). Depending on $\mathrm{N}^{6}$-substituent, CKs are classified as isoprenoid (e.g. zeatin) or aromatic compounds (e.g. BAP; Doležal et al. 2007). In plant cells, CKs are usually bound with $\beta$-D-ribose or $\beta$-D-glucose forming ribosides. Free adenine backbones are biologically the most active forms of CKs (Griffaut et al. 2004). However, biological activity of CKs depends mainly on the $\mathrm{N}^{6}$-substituent (Spíchal et al. 2004).

There are natural and synthetic CKs, but this classification is not clear. For instance, kinetin and BAP are sometimes called synthetic CKs, because in plants their amounts are so small that for commercial purposes they must be synthesized in chemical processes (van Staden et al. 2008). However, both kinetin and BAP were discovered in plants (Barciszewski et al. 2007), so in this paper we classified them as natural compounds.

Natural cytokinins may occur in different forms which include free bases, glucosidic conjugates, ribosides or nucleotides (van Staden et al. 2008). Among naturally occurring $\mathrm{CKs}$, there are compounds with an aliphatic substituent and this group of CKs is represented by isopentenyladenine (iP), zeatin (trans- and cis- isomers) and their derivates. Derivates of zeatin and iP as well as their sugar conjugates are most popular, but their occurrence depends on plant species, stage of development and tissue (Sakakibara 2006). Accordingly, trans-zeatin and iP are main forms in A. thaliana, while cis-zeatin predominates in rice, chickpea and maize (Sakakibara 2006).

Zeatin, an isoprenoid $\mathrm{CK}$, and its derivatives are the best described CK group (Gajdošová et al. 2011). Zeatin also occurs in nature as glucosidic conjugates as well as metabolites, e.g. dihydrozeatin which also exhibits $\mathrm{CK}$ activity (van Staden et al. 2008).

BAP, kinetin and $o$ - and $m$-topoline are CKs which have an aromatic substituent (Barciszewski et al. 2007; Kudo et al. 2012).

Benzylaminopurine and its derivates are active and readily available substances which stimulate growth and metabolism in plants; they are also commonly used in plant biotechnology (Doležal et al. 2007) and in micropropagation (van Staden et al. 2008). In different cultivars of bananas, BAP has recently been shown to induce shoot tip multiplication and to stimulate growth of axillary and adventitious buds and foliar development of shoot tip cultures (Jafari et al. 2011).

Kinetin (6-furfuryladenine), a purine-derived CK, discovered as a degradation product of DNA, plays a crucial role in plant cell division. It was isolated by Professor Scoog in 1955 and now it seems that it is the best-known CK (Barciszewski et al. 2007; van Staden et al. 2008). Kinetin was recognized as a synthetic by-product (Barciszewski et al. 2007) of herring sperm DNA autoclaving which suggested that it was not a natural compound (Minorsky 2003). However, in 1996, it was discovered that this CK occurred in commercially available DNA from human cells, human urine and from plants (Barciszewski et al. 2007). Natural kinetin was also identified in Casuarina equisetifolia root nodules nodulated by Frankia as well as in liquid endosperm of fresh young coconut fruits (Barciszewski et al. 2007).

Most experimental data showed strong antioxidant properties of kinetin and it was found to protect DNA against oxidative damage in Fenton reaction (Minorsky 2003). Nowadays, it is used in the rosacea therapy and plays a pivotal role in cosmetology because of its antiaging properties (Wu et al. 2007).

Synthetic CKs and some synthetic compounds have biological activity similar to natural CKs, some of them also have similar chemical construction, but the others exhibit only CK activity (Yonova 2010). Amino purine and non-amino purine synthetic CKs are known (van Staden et al. 2008).

Researchers created some synthetic compounds exhibiting CK activity (van Staden et al. 2008) because natural CKs are not used in commercial laboratories due to their 
cost. Mostly, they are $\mathrm{N}^{6}$-substituted adenine derivates, but they can also be less chemically related compounds, like 4-alkylaminopteridines or 6-benzyloxypurines (van Staden et al. 2008). Non-purine CKs are the biggest group of synthetic compounds with CK activity (Yonova 2010). This group contains the following subgroups: benzimidazoles, pyrimidines, $O$-6-substituted derivates of hypoxanthine, guanine and the most significant subgroup_-aromatic ureas.

\section{The way of perception and transduction of CK signals in planta}

Cytokinin receptors belong to a class of HK receptors (Shi and Rashotte 2012). These receptors act similarly to a twocomponent signal transduction system which resembles the typical model of a two-component system widely used by bacteria (Beier and Gross 2006) and some fungi (Schaller et al. 2011).

In the prototypical two-component system, the receptors consist of two proteins, a sensor and a response regulator (RR) (Fig. 1). Active forms of receptors are homo- or heterodimeric combinations. The sensor is made up of two domains: external and internal. The external domain is responsible for ligand binding and signal perception (Jeon and Kim 2012), whereas the internal domain, histidine phosphotransfer proteins (HPs), undergoes autophosphorylation and then subsequently transfers phosphoryl groups to RRs i. e. to downstream transcriptional activators or repressors in a nucleus where they can affect changes in cellular physiology (often by regulating gene expression; Laub and Goulian 2007).

A common variant of the canonical two-component signaling pathway was characterized in a number of plant species such as A. thaliana (Nishimura et al. 2004), Zea mays (Lomin et al. 2011; Spíchal et al. 2004), Oryza sativa (Ito and Kurata 2006), Medicago truncatula (GonzalezRizzo et al. 2006) and Glycine max (Mochida et al. 2010). In plants, the two-component $\mathrm{CK}$-signaling pathway is called multi-step phosphorelay.

Numerous examples indicate that the multi-step phosphorelay $\mathrm{CK}$ signaling plays a huge role in many physiological processes in the plant kingdom, including molecular, cellular and developmental regulations since embryo creation to tissue formation (shoot and root apical meristems, stem and root vascular systems, nodule) and organismal response to stress, pathogens, senescence (Hwang et al. 2012).

Cytokinin signals are perceived by the extracellular input domain of hybrid $\mathrm{HK}$ receptor named CHASE

\section{(a) TWO COMPONENT PHOSPHORELAY SYSTEM}

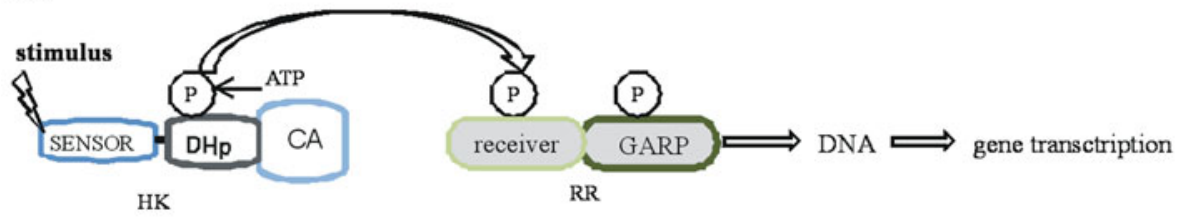

(b) MULTI -STEP PHOSPHORELAY SYSTEM

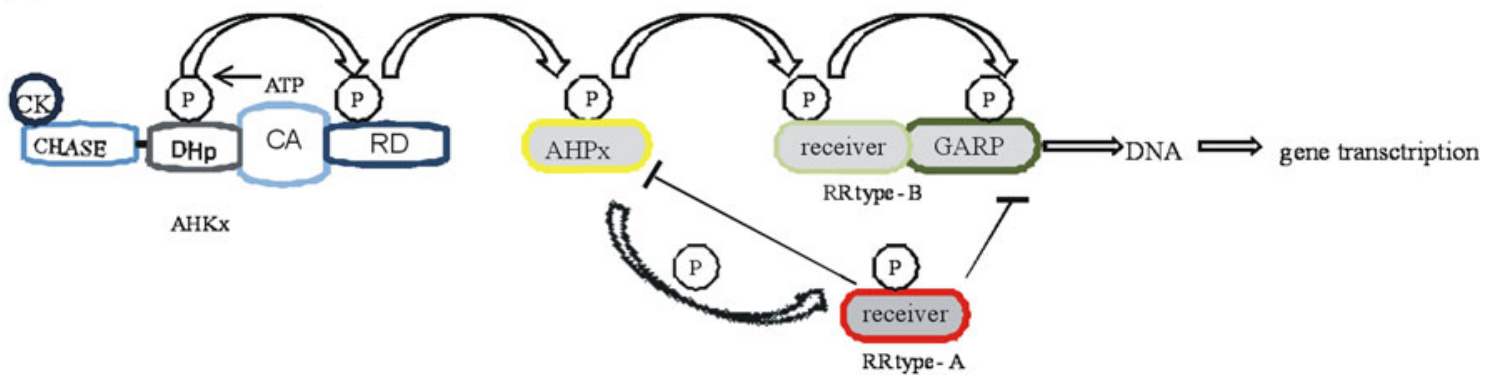

Fig. 1 a Two-component signaling system consists of a histidine kinase receptor (HK) and a response regulator (RR). The kinase receptor autophosphorylates a conserved histidine residue in response to a stimulus perceived by a sensor domain of HK. A phosphoryl group is transferred to a conserved aspartate residue of a receiver domain of the RR. The active RR subsequently triggers a response, usually acting as a transcription factor. DHp domain is a phosphodonor and mediates dimerization. CA domain is responsible for ATP binding and catalyzes autophosphorylation. CK-cytokinins, P-phosphoryl group AHKx: AHK2, AHK3, AHK4, DHp-histidine phosphotransferase domain, CA-catalytic domain, RD-receiver domain, AHPx: AHP1, AHP2, AHP3, AHP5; b A multi-step phosphorelay signaling system in Arabidopsis thaliana consists of a hybrid histidine kinase receptor (AHK), a histidine phosphotransfer protein (AHP) and a response regulator (ARR). Cytokinins are perceived by CHASE domains of AHK receptors localized both in plasma membrane and ER. CA domain is responsible for ATP binding and catalyzes autophosphorylation of a conserved histidine residue. DHp domain is a phosphodonor and mediates dimerization. RD shuttles phosphor to HP. Finally, HP moves phosphoryl group to a conserved aspartate of RR localized in the nucleus. Type-B RRs are transcription factors which switch on the expression of CK-regulated genes (including type-A RRs). Type-A RRs are engaged in repressing the CK signaling 
sensing domain (Kieber and Schaller 2010). Histidine kinases are hybrids because they have an additional receiver domain (Table 1). CHASE domain appears in mosses, lycophytes and higher plant. After ligand binding, the internal domain of the receptor, the histidine domain, undergoes autophosphorylation on a conserved histidine residue. Then, the high-energy phosphoryl group is transported to an aspartate histidine residue of the receiver domain of a histidine receptor (Bijlsma and Groisman 2003), after that the phosphoryl group is transferred by HP to an aspartate residue in $\mathrm{N}$-terminal of receiver domain of RR (Tables 2, 3; Laub and Goulian 2007). Output domains of the RRs named GARP are activated after phosphorylation of the receiver domain and are often involved in induction of core signaling components (Hwang et al. 2012). For details, see Fig. 2.

The multi-step phosphorelay system engaged in CK signaling is well known in A. thaliana. There are three $A$. thaliana HKs (AHK2, AHK3, AHK4) which are responsible for reception of the CK signals (Higuchi et al. 2004). Moreover, three A. thaliana HPs (AHP1, AHP2 and AHP5) that mediate phosphoryl group transfer between AHKs and ARRs were also characterized (Punwani et al. 2010). These AHPs act as positive regulators of CK signaling (Hutchison et al. 2006). They occur both in cytoplasm and nucleus (Grefen and Harter 2004). The RRs, final elements of CK perception and signal transduction, are divided into 4 subgroups i. e. type-A, type-B, type-C and APRRs (Arabidopsis pseudo-RRs). Type-A and type-B are involved in the CK-signaling pathway (Mizuno 2004).

Type-A ARRs consist of 10 RRs -3, 4, 5, 6, 7, 8, 9, 15, 16, 17. These RRs are small proteins. They carry an Aspcontaining receiver domain and a short C-terminal output domain. They function as primary transcriptional targets of CKs; their transcripts are accumulated fast after CKs treatment (Mizuno 2004). Most of type-A ARRs were found to be localized in the nucleus. They were reported to be mainly negative regulators of CK signaling (To et al. 2007).

Type-B ARRs consist of 11 RRs -1, 2, 10, 11, 12, 13, 14,18, 19, 20 (Argueso et al. 2012). They have longer C-terminal receiver domains than type-A ARRs (Argyros et al. 2008), binding with DNA and a trans-activating motif (To et al. 2007). They play a role of positive regulators of CK signaling (Hwang et al. 2012) which monitor the transcription of many CK-regulated targets including the induction of type-A ARRs (To et al. 2007; Rashotte et al. 2006).

The specific CK signaling multi-step phosphorelay system was also characterized in M. truncatula (MT, Gonzalez-Rizzo et al. 2006), where one HK (MtCRE1) and two RRs of type-A (MtRR4) and type-B (MtRR1) were identified. This CK-signaling pathway was observed during

Table 1 AHK and AHP engaged in CK signaling, their interaction, function and localization

\begin{tabular}{|c|c|c|c|}
\hline $\begin{array}{l}\text { Elements } \\
\text { engaged in } \\
\text { CK-signaling }\end{array}$ & $\begin{array}{l}\text { Interaction between } \\
\text { elements engaged } \\
\text { in CK-signaling }\end{array}$ & Functions of the elements engaged in CK-signaling & $\begin{array}{l}\text { Localization in planta and } \\
\text { plant cells }\end{array}$ \\
\hline \multicolumn{4}{|l|}{ AHK } \\
\hline AHK2 & ARR2 & $\begin{array}{l}\text { Increases CK-dependent ARR6 promoter activity, engaged } \\
\text { in cold response }\end{array}$ & $\begin{array}{l}\text { Root and leaf vasculatures, } \\
\text { shoot meristems, root tips } \\
\text { stems, flowers }\end{array}$ \\
\hline AHK3 & ARR3 & $\begin{array}{l}\text { Increases CK-dependent ARR6 promoter activity } \\
\text { senescence and root development, engaged cold response }\end{array}$ & $\begin{array}{l}\text { Root and leaf vasculatures, } \\
\text { shoot meristems, root tips, } \\
\text { stems, flowers }\end{array}$ \\
\hline AHK4 & AHP2/AHP5 > AHP3 & $\begin{array}{l}\text { Increases CK-dependent ARR6 promoter activity, engaged } \\
\text { in senescence and root development, controls root } \\
\text { meristem size, PCD }\end{array}$ & $\begin{array}{l}\text { Root and leave vasculatures, } \\
\text { shoot meristems, root tips, } \\
\text { stems, flowers }\end{array}$ \\
\hline \multicolumn{4}{|l|}{ AHP } \\
\hline AHP1 & $\begin{array}{l}\text { ARR1, ARR2, ARR4, } \\
\text { ARR9 and ARR10 }\end{array}$ & $\begin{array}{l}\text { Positive regulators of CK signaling, translocates signals } \\
\text { from cytoplasm to nucleus upon CK treatment }\end{array}$ & Leaves, roots, seedlings \\
\hline AHP2 & $\begin{array}{l}\text { ARR1, ARR2, RR10, } \\
\text { AHK4 }\end{array}$ & $\begin{array}{l}\text { Positive regulators of CK signaling, translocates signals } \\
\text { from cytoplasm to nucleus upon CK treatment, positive } \\
\text { factor in cold response }\end{array}$ & $\begin{array}{l}\text { Roots, leaves, stems, seedlings, } \\
\text { flowers }\end{array}$ \\
\hline AHP3 & $\begin{array}{l}\text { ARR1, ARR10, AHK4, } \\
\text { ARR9 }\end{array}$ & $\begin{array}{l}\text { Positive regulators of CK signaling, positive factor in cold } \\
\text { response }\end{array}$ & $\begin{array}{l}\text { Roots, leaves, stems, seedlings, } \\
\text { flowers }\end{array}$ \\
\hline AHP5 & ARR1 & $\begin{array}{l}\text { Translocates signals from cytoplasm to nucleus upon CK } \\
\text { treatment }\end{array}$ & Roots, leaves, stems, flowers \\
\hline
\end{tabular}

To et al. (2004); Hwang et al. (2012); Argyros et al. (2008); Heyl and Schmülling 2003; Hirose et al. (2008); Tajima et al. (2004); Mason et al. (2004); Kiba et al. (2003); Kiba et al. 2002; Jeon and Kim (2012); Zalabák et al. (2012); Shi and Rashotte (2012) 
Table 2 ARR type-A, negative, regulators of cytokinin signaling engaged in CK signaling, their interaction, function and localization (for references see Table 1)

\begin{tabular}{|c|c|c|c|}
\hline $\begin{array}{l}\text { Elements } \\
\text { engaged in CK- } \\
\text { signaling }\end{array}$ & $\begin{array}{l}\text { Interaction between } \\
\text { elements engaged in } \\
\text { CK-signaling }\end{array}$ & Functions of the elements engaged in CK-signaling & $\begin{array}{l}\text { Localization in planta and plant } \\
\text { cells }\end{array}$ \\
\hline ARR3 & ARR9 & Regulation of petiole elongation & Root and leaf vasculatures \\
\hline ARR4 & AHP1 & $\begin{array}{l}\text { Represses CK induced transcription of ARR6, renders tissues } \\
\text { more CK sensitive, induced by osmotic stress, regulates of } \\
\text { petiole elongation, engaged in environmental stresses such as } \\
\text { drought, salt etc., signaling module in cytokinin and light } \\
\text { signal transduction pathways }\end{array}$ & Root and leaf vasculatures \\
\hline ARR5 & No data & $\begin{array}{l}\text { Represses CK induced transcription of ARR6, engaged in } \\
\text { osmotic stress and environmental stresses such as drought, } \\
\text { salt etc. }\end{array}$ & $\begin{array}{l}\text { Shoot and root meristems, } \\
\text { leaves, fruit abscission zones }\end{array}$ \\
\hline ARR6 & No data & Represses CK induced transcription of ARR6 & $\begin{array}{l}\text { Roots, leaf and shoot } \\
\text { vasculatures, root meristems }\end{array}$ \\
\hline ARR7 & No data & Represses CK induced transcription of ARR6 & $\begin{array}{l}\text { Inflorescence, shoot apical } \\
\text { meristem, }\end{array}$ \\
\hline ARR8 & No data & $\begin{array}{l}\text { Renders transgenic overexpression CK insensitive, } \\
\text { engaged in osmotic stress }\end{array}$ & $\begin{array}{l}\text { Root tips, root meristems, root } \\
\text { vasculatures, leaf } \\
\text { vasculatures, anthers }\end{array}$ \\
\hline ARR9 & AHP1, AHP3 and ARR3 & No data & $\begin{array}{l}\text { Root tips, root meristems, root } \\
\text { vasculatures, leaf vasculatures }\end{array}$ \\
\hline ARR15 & No data & No data & Root tips \\
\hline ARR16 & No data & No data & No data \\
\hline ARR17 & No data & No data & No data \\
\hline ARR20 & No data & No data & $\begin{array}{l}\text { Pistils, flowers, leaf } \\
\text { vasculatures, shoot meristems }\end{array}$ \\
\hline
\end{tabular}

Table 3 ARR type-B, positive, regulators of cytokinin signaling engaged in CK signaling, their interaction, function and localization (for references see Table 1)

\begin{tabular}{|c|c|c|c|}
\hline $\begin{array}{l}\text { Elements } \\
\text { engaged in } \\
\text { CK-signaling }\end{array}$ & $\begin{array}{l}\text { Interaction between } \\
\text { elements engaged in } \\
\text { CK-signaling }\end{array}$ & Functions of the elements engaged in CK-signaling & $\begin{array}{l}\text { Localization in planta and plant } \\
\text { cells }\end{array}$ \\
\hline ARR1 & $\begin{array}{l}\text { AHP1, AHP2 and } \\
\text { AHP3 }\end{array}$ & $\begin{array}{l}\text { Activates transcription of CK response genes, its } \\
\text { overexpression causes aberrant cell proliferation essential and } \\
\text { redundant roles during cytokinin signaling }\end{array}$ & Young leaves, anthers, root tips \\
\hline ARR2 & $\begin{array}{l}\text { AHK2 and AHK3 } \\
\text { AHP2 }\end{array}$ & $\begin{array}{l}\text { Activates transcription of CK response genes, its } \\
\text { overexpression promotes cell proliferation and shoot growth, } \\
\text { engaged in cold response }\end{array}$ & $\begin{array}{l}\text { Pollens, leaf and root } \\
\text { vasculatures, young leaves, } \\
\text { shoot meristems, root tips }\end{array}$ \\
\hline ARR10 & AHP1, AHP2, AHP3 & $\begin{array}{l}\text { Activates transcription of ARR6, the head of a transcriptional } \\
\text { cascade to regulate the cytokinin response }\end{array}$ & $\begin{array}{l}\text { Roots, leaf vasculatures, shoot } \\
\text { meristems }\end{array}$ \\
\hline ARR11 & AHP2 & $\begin{array}{l}\text { Binds DNA specifically and activates transcription } \\
\text { overexpression causes aberrant cell proliferation }\end{array}$ & Shoot meristems, young leaves \\
\hline ARR12 & No data & $\begin{array}{l}\text { The head of a transcriptional cascade to regulate the cytokinin } \\
\text { response }\end{array}$ & $\begin{array}{l}\text { Young leaves, developing seeds } \\
\text { and roots, leaf vasculatures }\end{array}$ \\
\hline ARR13 & No data & No data & $\begin{array}{l}\text { Young leaves and flowers, leaf } \\
\text { vasculatures }\end{array}$ \\
\hline ARR14 & No data & No data & Young leaves \\
\hline ARR18 & No data & No data & $\begin{array}{l}\text { Young leaves and flowers, } \\
\text { flowers, shoot meristems }\end{array}$ \\
\hline ARR19 & No data & No data & Trichome \\
\hline ARR20 & No data & No data & $\begin{array}{l}\text { Young leaves, leaf vasculatures, } \\
\text { shoot meristems, pistils }\end{array}$ \\
\hline
\end{tabular}




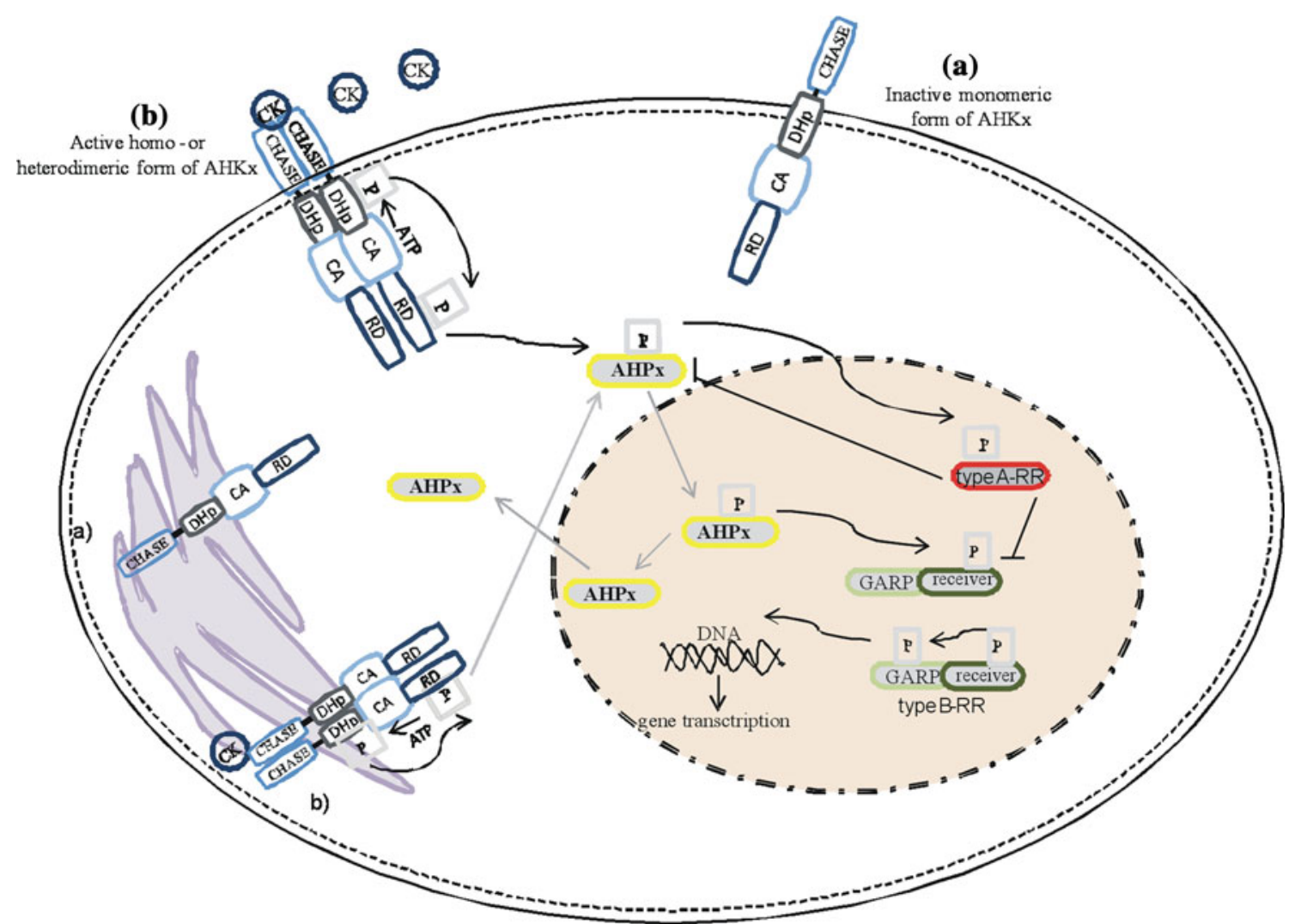

Fig. 2 A model of cytokinin multi-step phosphorelay signaling system in Arabidopsis thaliana. a Inactive form of histidine kinase receptor (AHKx). b Active form of histidine kinase receptor after ligand $(\mathrm{CK})$ binding (mono- or heterodimeric combination of AHKs). For details, see Fig. 1 legend

AHP2, AHP3 and AHP5. The other two HK proteins, GmHP07 and GmHP08, are in close relationship to AHP4, and they might be negative regulators of CK signaling. The RRs engaged in CK signaling appearing in soybean are reported to be type-A ARRs and type-B ARRs. Type-A RRs (GmRR01, GmRR02, GmRR03, GmRR06, GmRR09, GmRR10, GmRR18) were described as negative regulators of CK signaling, whereas type-B (GmRR25, GmRR26, GmRR29) seems also to play a positive role in transcription factors engaged in CK signaling (Mochida et al. 2010).

Cytokinin-responsive His-protein kinases were also identified in Z. mays (ZmHK1, ZmHK2, ZmHK3a). They were closely related to AHK4, AHK3, and AHK2 receptors, respectively (Lomin et al. 2011). Three HPs (ZmHP1, ZmHP2, ZmHP3) and ten RRs (ZmRR1 to ZmRR10) were also detected in Z. mays. In this plant, HPs also play a significant role in signal integration and their transduction between HK and RR (Yonekura-Sakakibara et al. 2004). In maize, RRs which regulate cellular responses to $\mathrm{CKs}$ (Asakura et al. 2003) can be also classified into two types: type-A of RRs (ZmRR1, ZmRR2 and ZmRR4 to ZmRR7) and type-B of RRs (ZmRR8-ZmRR10). 


\section{Cellular and sub-cellular localization of multi-step cytokinin signaling components}

Cytokinin receptors have been widely studied (Kieber and Schaller 2010; Dortay et al. 2008; Gupta and Rashotte 2012). Their biochemical properties and specific functions were examined, but their cellular localization is still not fully investigated. Researches focused on AHK3 and AHK4 in A. thaliana. Firstly, Kim et al. (2006) reported that a CK signal was perceived by AHK3 at the plasma membrane. However, later it was indicated that AHK3 and AHK4 were mostly localized in ER (Wulfetange et al. 2011) or both in plasma membrane and endoplasmic reticulum (Shi and Rashotte 2012; Nongpiur et al. 2012).

The AHP proteins were found to be localized both in cytoplasm and nucleus. It seems that they undergo bulk relocalization between nucleus and cytoplasm. However, their relocalization seems to be independent of the CKsignaling pathway (Punwani et al. 2010).

Localization of A- and B-type RR proteins was only detected in a nucleus, apart from two type-A ARRs, ARR3 and ARR16, for which localization in the cytosol was described. Nonetheless, a low signal of these two abovementioned RRs could be also detected in the nucleus (Dortay et al. 2008).

\section{Role of cytokinin and their signaling during programmed cell death}

Programmed cell death process is apparently under hormonal control. Plant hormones such as ethylene, brassinosteroids and CKs together with other signaling compounds regulate PCD process in a complex way (Gadjev et al. 2008). It is well known that in cereal aleurone cells, PCD is induced by gibberellins, while, ABA blocks the effect of gibberellins and delays this process (Carimi et al. 2003). Recently, studies have shown that high levels of CKs such as BAP and kinetin (Carimi et al. 2004; Kunikowska et al. 2012; Vescovi et al. 2012) are also able to induce PCD in plant tissues and cell cultures (Carimi et al. 2003, 2004; Kunikowska et al. 2012). High concentration of BAP $(27 \mu \mathrm{M})$ induced PCD in cell cultures of carrot (Daucus carota) and A. thaliana (L.) Heynh. In both carrot and Arabidopsis, PCD was induced by accelerating senescence or senescence-like process both in vitro (in cell cultures) and in vivo (in leaves; Carimi et al. 2004; Vescovi et al. 2012), but the oligo nucleosomal nuclear DNA fragmentation-one of the PCD hallmarks (Palavan-Unsal et al. 2005)—was observed only in cell cultures. This observation suggested that cell cultures might be used as a model system to study senescence (Carimi et al. 2004). Additional PCD hallmarks induced by
BAP include chromatin condensation and release of cytochrome c. The DNA fragmentation in carrot was detected at lower concentration of BAP $(13 \mu \mathrm{M}$; Carimi et al. 2003). The BAP-induced PCD process was accompanied by decreased cell growth and blocked cell division; however, it seems that BAP might induce PCD not only by limiting cell proliferation (Carimi et al. 2003).

More recently, it has been reported that kinetin is able to induce PCD in planta, i.e. in root cortex cells of Vicia faba ssp. minor (Kunikowska et al. 2012), but not in human and animal cells (Berge et al. 2006; Ishii et al. 2002). Doublecolored staining with acridine orange (AO) and ethidium bromide (EB) showed that kinetin induced cell death in mid cortex cells, but not in meristem. The activity of dehydrogenases secreted from mitochondria (about $40 \%$ ) was correlated with the amount of living root cortex cells (about $40 \%$ ) and the number of retained mitochondria (about $45 \%$ ). There are also characteristic morphological changes in nuclei which include chromatin condensation, micronuclei formation, invagination, chromatin degradation and fragmentation of nuclei, which was shown both by $\mathrm{AO} / \mathrm{EB}$ and DAPI staining. Kinetin also decreases root lengths and simultaneously increases their weight and width. Moreover, it induces acidic vacuole formation as well as increases the amount of calcium ions. Production of ROS is also observed (Kunikowska et al. 2012).

Other studies of CKs, e.g. on cultured cells of A. thaliana and $D$. carota showed that zeatin did not induce a PCD process (Carimi et al. 2004). It may result from the fact that chemical structures of BAP, kinetin and zeatin are different so these compounds have varied ability to induce PCD (van Staden et al. 2008; Carimi et al. 2004; Kunikowska et al. 2012).

The question arises how CKs are able to induce this process. There are CK receptors acting as HK, CK HP and CK RR that create a specific system of reception and transduction of CK signals named multi-step phosphorelay system (Ferreira and Kieber 2005). Some results indicate that one of the A. thaliana CK receptors (AHK4) is engaged in CK-stimulated induction of PCD (Vescovi et al. 2012) This discovery confirmed a central role of AHK4 and excluded participation of two other AHKs named AHK2 and AHK3 in mediating CK (BAP)-induced PCD. Moreover, it has been explained why such a high level of CKs is necessary to induced PCD. Vescovi et al. (2012) showed that AHK4 had low affinity to applied CK. It seems that HK receptors may be also engaged in the mechanism of kinetin-induced cell death (Kunikowska et al. 2012). It has been proposed that phosphoribosyl transferase converts kinetin to monophosphates (Kunikowska et al. 2012), purine ligands specific for HKs receptors (AHK2, AHK3 and $\mathrm{AHK}$ ), which were discovered in plasma membrane and endoplasmic reticulum membranes of Zea mays and Arabidopsis (Caesar et al. 2011). 


\section{Future directions}

Subcellular AHK localization sheds a new light on hormone functioning (Caesar et al. 2011) during PCD process (Vescovi et al. 2012). The ER localization may explain why CK signal is perceived by different subcellular localizations and through distinct CK metabolites (Wulfetange et al. 2011). Unfortunately, there are still no reports concerning the role of the other two elements (AHPs and ARRs) of the CK-signaling multi-step system in PCD process. Recently, multi-step signal transduction system has been described in a lot of plant species (Vescovi et al. 2012; Lomin et al. 2011). It is involved in many physiological processes, and thus it is possible to create models of the remaining elements of the system engaged in PCD and of their interactions. Some morphological and metabolical features observed during PCD in root cortex cells of $V$. faba ssp. minor after kinetin treatment (Kunikowska et al. 2012) might be related to the multi-step signal transduction system.

Acknowledgments We thank Ms. M. Fronczak for her help in preparing this manuscript in English. This work was partially supported by grant from the University of Łódź, No. 545/487 and $545 / 502$.

Conflict of interest The authors declare that they have no conflict of interest.

Open Access This article is distributed under the terms of the Creative Commons Attribution License which permits any use, distribution, and reproduction in any medium, provided the original author(s) and the source are credited.

\section{References}

Argueso CT, Ferreira FF, Epple P, To JPC, Hutchison CE, Schaller GE, Dangl JL, Kieber JJ (2012) Two-component elements mediate interactions between cytokinin and salicylic acid in plant immunity. PLoS Genet 8:1002-1448

Argyros RD, Mathews DE, Chiang Y, Palmer CM, Thibault DM, Etheridge N, Argyros DA, Mason MG, Kieber JJ, Schallera GE (2008) Type B response regulators of Arabidopsis play key roles in cytokinin signaling and plant development. Plant Cell 20:2102-2116

Ariel F, Brault-Hernandez M, Laffont C, Huault E, Brault M, Plet J, Moison M, Blanchet S, Ichanté JL, Chabaud M, Carrere S, Crespi M, Chan RL, Frugiera F (2012) Two direct targets of cytokinin signaling regulate symbiotic nodulation in Medicago truncatula. Plant Cell 24:3838-3852

Asakura Y, Hagino T, Ohta Y, Aoki K, Yonekura-Sakakibara K, Deji A, Yamaya T, Sugiyama T, Hitoshi Sakakibara H (2003) Molecular characterization of His-Asp phosphorelay signaling factors in maize leaves: implications of the signal divergence by cytokinin-inducible response regulators in the cytosol and the nuclei. Plant Mol Biol 52:331-341

Barciszewski J, Massino F, Clark BFC (2007) Kinetin- A multiactive molecule. Int J Biol Macromol 40:182-192
Beier D, Gross R (2006) Regulation of bacterial virulence by twocomponent systems. Curr Opi Microbiol 9:143-152

Berge U, Kristensen P, Rattan SIS (2006) Kinetin-induced differentiation of normal human keratinocytes undergoing aging in vitro. Ann NY Acad Sci 1067:332-336

Bijlsma JJE, Groisman EA (2003) Making informed decisions: regulatory interactions between two-component systems. Trends Microbiol 11:359-366

Caesar K, Thamm AMK, Witthöft J, Elgass K, Huppenberger P, Grefen C, Horak J, Harter K (2011) Evidence for the localization of the Arabidopsis cytokinin receptors AHK3 and AHK4 in the endoplasmic reticulum. J Exp Bot 62(15):5571-5580

Carimi F, Zottini M, Formentin E, Terzi M, Lo Schavio F (2003) Cytokinins: new apoptotic inducers in plants. Planta 216:413421

Carimi F, Terzi M, De Michele R, Zottini M, Lo Schiavo F (2004) High levels of the cytokinin BAP induce PCD by accelerating senescence. Plant Sci 166:963-969

Choi J, Hwang I (2007) Cytokinin: perception, signal transduction, and role in plant growth and development. J Plant Biol 50:98-108

Choi J, Choi D, Lee S, Ryu C, Hwang I (2011) Cytokinins and plant immunity: old foes or new friends? Trends Plant Sci 16(7):388-394

Collazo C, Chacón O, Borrás O (2006) Programmed cell death in plants resembles apoptosis of animals. Biotecnol Apl 23:1-10

Doi K, Izawa T, Fuse T, Yamanouchi U, Kubo T, Shimatani Z, Yano M, Yoshimura A (2004) Ehd1, a B-type response regulator in rice, confers short-day promotion of flowering and controls FT-like gene expression independently of Hd1. Genes Dev 18:926-936

Doležal K, Popa I, Haserova E, Spichal L, Strnad M (2007) Preparation, biological activity and endogenous occurrence of $\mathrm{N}^{6}$-benzyladenosines. Bioorg Medicinal Chem 15:3737-3747

Dortay H, Gruhn N, Pfeifer A, Schwerdtner M, Schmülling T, Heyl A (2008) Toward an interaction map of the two-component signaling pathway of Arabidopsis thaliana. J Proteome Res 7:3649-3660

Ferreira FJ, Kieber JJ (2005) Cytokinin signaling. Curr Opin Plant Biol 8:518-525

Gadjev I, Stone JM, Gechev TS (2008) Programmed cell death in plants: new insights into redox regulation and the role of hydrogen peroxide. Int Rev Cell Mol Biol 270:87-144

Gajdošová S, Spíchal L, Kamínek M, Hoyerová K, Novák O, Dobrev PI, Galuszka P, Klíma P, Gaudinová A, Žižková E, Hanuš J, Danč ák M, Trávníček B, Pešek B, Krupička M, Vaňková R, Strnad M, Motyka V (2011) Distribution, biological activities, metabolism, and the conceivable function of cis-zeatin-type cytokinins in plants. J Exp Bot 62(8):2827-2840

Gladish DK, Xu J, Niki T (2006) Apoptosis-like programmed cell death occurs in procambium and ground meristem of pea (Pisum sativum) root tips exposed to sudden flooding. Ann Bot 97:895-902

Gonzalez-Rizzo S, Crespi M, Frugier F (2006) The Medicago truncatula CRE1 cytokinin receptor regulates lateral root development and early symbiotic interaction with Sinorhizobium meliloti. Plant Cell 18:2680-2693

Grefen C, Harter K (2004) Plant two-component systems: principles, functions, complexity and cross talk. Planta 219:733-742

Griffaut B, Bos R, Maurizis J, Madelmont J, Ledoigt G (2004) Cytotoxic effects of kinetin riboside on mouse, human and plant tumour cells. Int J Biol Macromol 34:271-275

Gupta S, Rashotte AM (2012) Down-stream components of cytokinin signaling and the role of cytokinin throughout the plant. Plant Cell Rep 31:801-812

Heyl A, Schmülling T (2003) Cytokinin signal perception and transduction. Curr Opin Plant Biol 6:480-488 
Higuchi M, Pischke MS, Mähönen AP, Miyawaki K, Hashimoto Y, Seki M, Kobayashi M, Shinozaki K, Kato T, Tabata S (2004) In planta functions of the Arabidopsis cytokinin receptor family. Proc Natl Acad Sci 101:8821-8826

Hirose N, Takei K, Kuroha T, Kamada-Nobusada T, Hayashi H, Sakakibara H (2008) Regulation of cytokinin biosynthesis, compartmentalization and translocation. J Exp Bot 59:75-83

Hutchison CE, Li J, Argueso C, Gonzalez M, Lee E, Lewis MW, Maxwell BB, Perdue TD, Schaller GE, Alonso JM, Ecker JR, Kieber JJ (2006) The Arabidopsis histidine phosphotransfer proteins are redundant positive regulators of cytokinin signaling. Plant Cell 18:3073-3087

Hwang I, Sheen J, Müller B (2012) Cytokinin signaling networks. Annu Rev Plant Biol 63:353-380

Ishii Y, Hori Y, Sakai S, Honma Y (2002) Control of differentiation and apoptosis of human myeloid leukemia cells by cytokinins and cytokinin nucleosides, plant redifferentiation-inducing hormones. Cell Growth Differ 13:19-26

Ito Y, Kurata N (2006) Oryza sativa Identification and characterization of cytokinin-signalling gene families in rice. Gene 382:57-65

Jafari N, Othman RY, Khalid N (2011) Effect of benzylaminopurine (BAP) pulsing on in vitro shoot multiplication of Musa acuminata (banana) cv. Berangan. Afr J Biotechnol 10:2446-2450

Jeon J, Kim J (2012) Arabidopsis response regulator 1 (ARR1) and Arabidopsis histidine phosphotransfer protein 2 (AHP2), AHP3, and AHP5 function in cold signaling. Plant Physiol. doi: 10.1104/pp.112.207621

Kiba T, Yamada H, Mizuno T (2002) Characterization of the ARR15 and ARR16 response regulators with special reference to the cytokinin signalling pathway mediated by the AHK4 histidine kinase in roots of Arabidopsis thaliana. Plant Cell Physiol 43:1059-1066

Kiba T, Yamada H, Sato S, Kato T, Tabata S, Yamashino T, Mizuno $\mathrm{T}$ (2003) The type-A response regulator, ARR15, acts as a negative regulator in the cytokinin-mediated signal transduction in Arabidopsis thaliana. Plant Cell Physiol 44(8):868-874

Kieber JJ, Schaller GE (2010) The perception of cytokinin: a story 50 years in the making. Plant Physiol 154:487-492

Kim HJ, Ryu H, Hong SH, Woo HR, Lim PO, Lee IC, Sheen J, Nam HG, Hwang I (2006) Cytokinin-mediated control of leaf longevity by AHK3 through phosphorylation of ARR2 in Arabidopsis. PNAS 103:814-819

Kudo T, Makita N, Kojima M, Tokunaga H, Sakakibara H (2012) Cytokinin activity of cis-zeatin and phenotypic alterations induced by overexpression of putative cis-zeatin- $O$-glucosyltransferase in rice. Plant Physiol 160:319-331

Kunikowska A, Byczkowska A, Kaźmierczak A (2012) Kinetin induces cell death in root cortex cells of Vicia faba ssp. minor seedlings. Protoplasma. doi:10.1007/s00709-012-0466-7

Laub MT, Goulian M (2007) Specificity in two-component signal transduction pathways. Annu Rev Genet 41:121-145

Lomin SN, Yonekura-Sakakibara K, Romanov GA, Sakakibara H (2011) Ligand-binding properties and subcellular localization of maize cytokinin receptors. J Exp Bot 62:5149-5159

Mason MG, Li J, Mathews DE, Kieber JJ, Schaller GE (2004) Type-B response regulators display overlapping expression patterns in Arabidopsis. Plant Physiol 135:927-937

Mazid M, Khan TA, Mohammad F (2011) Cytokinins, a classical multifaceted hormone in plant system. J Stress Physiol Biochem $7: 347-368$

Minorsky PV (2003) The hot and the classic. Plant Physiol 132:1135-1136

Mizuno T (2004) Plant response regulators implicated in signal transduction and circadian rhythm. Curr Op Plant Biol 7:1-7
Mochida K, Yoshida T, Sakurai T, Yamaguchi-Shinozaki K, Shinozaki K, Tran LP (2010) Genome-wide analysis of two-component systems and prediction of stress-responsive two-component system members in soybean. DNA Res 17:303-324

Nishimura C, Ohashi Y, Sato S, Kato T, Tabata S, Ueguchia C (2004) Histidine kinase homologs that act as cytokinin receptors possess overlapping functions in the regulation of shoot and root growth in Arabidopsis. Plant Cell 16:1365-1377

Nongpiur R, Soni P, Karan R, Singla-Pareek SL, Pareek A (2012) Histidine kinases in plants: cross talk between hormone and stress responses. Plant Signal Behav 7(10):1230-1237

Palavan-Unsal N, Buyuktuncer ED, Tufekci MA (2005) Programmed cell death in plants. J Cell Mol Biol 4:9-23

Punwani JA, Hutchison CE, Schaller GE, Kieber JJ (2010) The subcellular distribution of the Arabidopsis histidine phosphotransfer proteins is independent of cytokinin signaling. Plant $\mathbf{J}$ 62:473-482

Rashotte AM, Mason MG, Hutchison CE, Ferreira FJ, Schaller GE, Kieber JJ (2006) A subset of Arabidopsis AP2 transcription factors mediates cytokinin responses in concert with a twocomponent pathway. PNAS 103:11081-11085

Sakakibara H (2006) Cytokinins: activity, biosynthesis, and translocation. Annu Rev Plant Biol 57:431-449

Schaller GE, Shiu S, Armitage JP (2011) Two-component systems and their co-option review for eukaryotic signal transduction. Curr Biol 21:320-330

Shi X, Rashotte AM (2012) Advances in upstream players of cytokinin phosphorelay: receptors and histidine phosphotransfer proteins. Plant Cell Rep 31:789-799

Spíchal L, Rakova N, Riefler M, Mizuno T, Romanov GA, Strnad M, Schmülling T (2004) Two cytokinin receptors of Arabidopsis thaliana, CRE1/AHK4 and AHK3, differ in their ligand specificity in a bacterial assay. Plant Cell Physiol 45:1299-1305

Tajima Y, Imamura A, Kiba T, Amano Y, Yamashino T, Mizuno T (2004) Comparative studies on the Type-B response regulators revealing their distinctive properties in the His-to-Asp phosphorelay signal transduction of Arabidopsis thaliana. Plant Cell Physiol 45:28-39

To JPC, Haberer G, Ferreira FJ, Deruère J, Mason MG, Schaller GE, Alonso JM, Ecker JR, Kieber JJ (2004) Type-A Arabidopsis response regulator are partially redundant negative regulators of cytokinin signaling. Plant Cell 16:658-671

To JPC, Deruère J, Maxwell BB, Morris VF, Hutchison CE, Ferreira FJ, Schaller GE, Kieber JJ (2007) Cytokinin regulates Type-A Arabidopsis response regulator activity and protein stability via two-component phosphorelay. Plant Cell 19:3901-3914

Tsai Y, Weir NR, Hill K, Zhang W, Kim HJ, Shiu S, Schaller GE, Kieber JJ (2012) Characterization of genes involved in cytokinin signaling and metabolism from rice. Plant Physiol 158:1666-1684

van Doorn WG (2011) Classes of programmed cell death in plants, compared to those in animals. J Exp Bot 62(14):4749-4761

van Doorn WG, Beers EP, Dangl JL, Franklin-Tong VE, Gallois P, Hara-Nishimura I, Jones AM, Kawai-Yamada M, Lam E, Mundy J, Mur LA, Petersen M, Smertenko A, Taliansky M, van Breusegem F, Wolpert T, Woltering E, Zhivotovsky B, Bozhkov PV (2011) Morphological classification of plant cell deaths. Cell Death Differ 18(8):1241-1246

van Staden J, Zazimalova E, George EF (2008) Plant growth regulators II: cytokinins, their analogues and antagonists. In: George EF, Hall MA, De Klerk G-J (eds) Plant propagation by tissue culture, 3rd edn. Springer, The Netherlands, pp 205-226

Vescovi M, Riefler M, Gessuti M, Novák O, Schmülling T, Lo Schiavo F (2012) Programmed cell death induced by high levels of cytokinin in Arabidopsis cultured cells is mediated by the cytokinin receptor CRE1/AHK4. J Exp Bot. doi:10.1093/ jxb/ers008 
Wu JJ, Weinstein GD, Kricorian GJ, Kormeili T, McCullough JL (2007) Topical kinetin $0.1 \%$ lotion for improving the signs and symptoms of rosacea. Clin Exp Dermatol 32:693-695

Wulfetange K, Lomin SN, Romanov GA, Stolz A, Heyl A, Schmülling T (2011) The cytokinin receptors of Arabidopsis are located mainly to the endoplasmic reticulum. Plant Physiol 156:1808-1818

Yonekura-Sakakibara K, Kojima M, Yamaya T, Sakakibara H (2004) Molecular characterization of cytokinin-responsive histidine kinases in maize. Differential ligand preferences and response to cis-zeatin. Plant Physiol 134:1654-1661

Yonova P (2010) Design, synthesis and properties of synthetic cytokinins. Gen Appl Plant Physiol 36:124-147

Zalabák D, Pospíśilová H, Šmehilová M, Mrízová K, Frébort I, Galuszka P (2012) Genetic engineering of cytokinin metabolism: prospective way to improve agricultural traits of crop plants. Biotechnol Adv 31(1):97-117. doi:10.1016/j.biotechadv.2011. 12.003 